Aspirasi: Jurnal Masalah-Masalah Sosial | Volume 11, No. 1 Juni 2020

ISSN: 2086-6305 (print) ISSN: 2614-5863 (electronic)

doi: 10.22212/aspirasi.v11i1.1523

link online: http://jurnal.dpr.go.id/index.php/aspirasi/index

\title{
Penyelenggaraan Keamanan Pangan sebagai Salah Satu Upaya Perlindungan Hak Masyarakat sebagai Konsumen
}

\section{Food Safety Handling as One of the Community Protection Efforts as a Consumer}

\section{Tri Rini Puji Lestari}

\author{
tri.lestari@dpr.go.id \\ Pusat Penelitian Badan Keahlian DPR RI \\ Jl. Gatot Subroto, Senayan, Jakarta
}

Naskah diterima: 3 Januari 2020 | Naskah direvisi: 5 Juni 2020 | Naskah diterbitkan: 30 Juni 2020

\begin{abstract}
Consuming unsafe food can endanger the health and lives of consumers. But until now, the circulation of unsafe food is still a problem for Indonesia. Even though the provisions regarding food safety have been regulated in the Law on Food and the Law on Health. This paper uses a literature study. The analysis uses theories and concepts in the literature as the main object to answer questions related to the conditions of the implementation of food safety in Indonesia and various factors that need to be considered in the implementation of food security so that the rights of the community as consumers can be protected. The findings show that at this time Indonesia adheres to multiple agency systems where the application of this system involves a long bureaucratic path and prone to the occurrence of sector egos in the implementation of food security. There are five technical factors recommended by the WHO in providing safe food, namely: maintaining cleanliness, preventing pollution, storing food at safe temperatures, heating food at the right temperature, and using water and raw materials that are safe for consumption. Guaranteed implementation of protection for the community from unsafe food is a major factor that must always be sought by all parties concerned.
\end{abstract}

Keywords: consumers; food; food safety; supervision

\begin{abstract}
Abstrak: Mengonsumsi pangan yang tidak aman dapat membahayakan kesehatan dan jiwa konsumen. Namun, hingga saat ini peredaran pangan yang tidak aman masih menjadi permasalahan bagi Indonesia. Meskipun ketentuan mengenai keamanan pangan sudah diatur dalam UndangUndang (UU) tentang Pangan dan UU tentang Kesehatan. Tulisan ini menggunakan studi pustaka. Analisis menggunakan teori dan konsep pada literatur sebagai objek utama untuk menjawab pertanyaan terkait bagaimana kondisi penyelenggaraan keamanan pangan di Indonesia dan berbagai faktor yang perlu diperhatikan dalam penyelenggaraan keamanan pangan agar hak masyarakat sebagai konsumen dapat terlindungi. Hasil temuan menunjukkan bahwa saat ini Indonesia menganut multiple agency system di mana penerapan sistem ini melibatkan jalur birokrasi yang panjang dan rawan terjadinya ego sektoral dalam penyelenggaraan keamanan pangan. Ada lima faktor teknis yang direkomendasikan oleh WHO dalam penyediaan pangan yang aman, yaitu: menjaga kebersihan, mencegah terjadinya pencemaran, menyimpan makanan pada suhu yang aman, memanaskan makanan pada suhu yang tepat, serta menggunakan air dan bahan baku yang aman dikonsumsi. Jaminan terselenggaranya perlindungan bagi masyarakat dari pangan yang tidak aman merupakan faktor utama yang harus selalu diupayakan oleh semua pihak terkait.
\end{abstract}

Kata Kunci: keamanan pangan; konsumen; pangan; pengawasan 


\section{Pendahuluan}

Pangan merupakan kebutuhan dasar manusia yang paling utama dan pemenuhannya juga merupakan bagian dari hak asasi manusia. Hak dasar manusia ini juga sudah dijamin dalam Undang-Undang Dasar Tahun 1945 Pasal 27 ayat (2) yang intinya menyatakan setiap warga negara mempunyai hak untuk mendapatkan penghidupan yang layak sebagai manusia, salah satunya adalah mengonsumsi pangan yang aman dikonsumsi. Perlindungan masyarakat dari peredaran pangan yang tidak aman merupakan jaminan yang harus didapat masyarakat sebagai konsumen. Hal ini sejalan dengan amanat Undang-Undang Nomor 8 Tahun 1999 tentang Perlindungan Konsumen (UU Perlindungan Konsumen) Pasal 4. Kondisi ini mengisyaratkan betapa pentingnya penanganan terkait masalah pangan agar pangan yang dikonsumsi masyarakat aman. Keamanan pangan merupakan persyaratan mutlak untuk suatu produk pangan.

Pangan merupakan makanan dan minuman yang mengandung sumber energi bagi tubuh agar dapat beraktivitas. Jika tubuh kekurangan energi, maka tubuh akan lemas dan mudah lelah. Selain itu, makanan dan minuman juga berfungsi untuk pertumbuhan dan perkembangan tubuh, pemeliharaan dan perbaikan sel-sel tubuh yang telah rusak atau tua, pengaturan metabolisme tubuh, pemeliharaan keseimbangan cairan tubuh, serta pertahanan tubuh terhadap penyakit. Makanan dan minuman yang baik bagi tubuh adalah makanan dan minuman yang bersih/ higienis, sehat dan bergizi seimbang (mengandung karbohidrat, lemak protein, vitamin, mineral, dan air), serta tidak mengandung bahanbahan yang membahayakan kesehatan tubuh (Nugraheni, Wiyatini, \& Wiradona, 2018: 129).

Terkait upaya pengamanan makanan dan minuman yang dikonsumsi manusia, Bagian Keenam Belas Pasal 109 Undang-Undang Nomor 36 Tahun 2009 tentang Kesehatan (UU tentang Kesehatan) telah mengatur bahwa makanan dan minuman yang diproduksi dan diedarkan ke masyarakat harus memenuhi standar atau kriteria aman dikonsumsi. Jika tubuh terus-menerus mengonsumsi makanan yang tidak aman dikonsumsi, maka tubuh akan rentan terkena masalah kesehatan. Jika kondisi ini terjadi pada anak-anak, dapat mengganggu proses tumbuh kembang anak termasuk pertumbuhan sel-sel otak yang dapat memengaruhi tingkat kecerdasan. Pada akhirnya anak tersebut akan sulit bersaing dengan anak-anak sebaya lainnya (Nugraheni, Wiyatini, \& Wiradona, 2018: 129).

Secara legal formal, upaya pengamanan pangan di Indonesia sudah mendapat perhatian dari pemerintah. Hal ini dibuktikan dengan adanya pengaturan terkait keamanan makanan dan minuman (pangan) dalam bentuk undangundang, seperti pada UU Kesehatan dan UndangUndang Nomor 18 Tahun 2012 tentang Pangan (UU Pangan) beserta peraturan pelaksanaannya.

Keamanan pangan merupakan salah satu faktor penting dalam penyelenggaraan sistem pangan. Pada ketentuan umum Peraturan Pemerintah Nomor 86 Tahun 2019 tentang Keamanan Pangan, penyelenggaraan keamanan pangan ditujukan agar negara dapat memberikan perlindungan kepada rakyat untuk mengonsumsi pangan yang aman bagi kesehatan dan keselamatan jiwa. Untuk menjamin pangan yang tersedia di masyarakat aman dikonsumsi, maka diperlukan penyelenggaraan keamanan pangan di sepanjang rantai pangan, mulai dari tahap produksi sampai ke tangan konsumen. Pada penyelenggaraan keamanan pangan, semua kegiatan atau proses produksi di dalam negeri maupun yang berasal dari impor untuk menghasilkan pangan yang aman dikonsumsi harus melalui penerapan persyaratan keamanan pangan.

Berbagai upaya penyelenggaraan keamanan pangan sudah dilakukan, di antaranya melalui penyelenggaraan pengawasan makanan dan minuman baik yang diproduksi di dalam negeri maupun produk impor. Namun demikian, masih saja kedapatan pangan yang beredar di masyarakat tidak memenuhi kriteria aman dikonsumsi. Sebagai contoh, hasil razia Dinkes Kabupaten Nganjuk di SD Mancong Kecamatan Wilangan Kabupaten Nganjuk, telah menemukan makanan jajanan di sekolah berupa sosis dan mie yang mengandung zat pewarna tekstil Rhodamin B. Padahal penggunaan pewarna tekstil Rhodamin $\mathrm{B}$ pada makanan dapat mengakibatkan gangguan fungsi hati dan jika dikonsumsi dalam jangka waktu lama akan memicu terjadinya kanker hati (Kartikasari, 2012: 4). Kondisi ini tentunya 
sangat mengkhawatirkan bagi orang tua murid, mengingat anak-anak SD tersebut masih dalam masa pertumbuhan dan merupakan generasi penerus bangsa.

Berdasarkan data Badan Pengawas Obat dan Makanan (BPOM), sampai dengan tanggal 10 Mei 2019, telah ditemukan dari 796 sarana gudang distributor, 170.119 kemasan produk pangan rusak, kadaluarsa, dan ilegal. Pada tahun 2018, dari 1.726 sarana ritel pangan yang diperiksa, didapat 591 sarana ritel yang tidak memenuhi ketentuan yaitu 110.555 kemasan dengan nilai keekonomian Rp2,2 miliar. Data BPOM tersebut menunjukkan adanya peningkatan jumlah kasus makanan tidak layak konsumsi, yaitu sebanyak 10\% dibanding tahun 2018 (Ulya, 2019). Kejadian ini hanya sebagian kecil yang tercatat dari kasus yang sebenarnya ada di masyarakat.

Makanan tidak layak konsumsi telah menyebabkan berbagai kasus keracunan. Kejadian keracunan makanan ini, selain menyebabkan sakit dan kematian, dapat juga mengakibatkan kerugian ekonomis yang sangat besar dan bahkan dapat berakibat pada kebangkrutan perusahaan. Berdasarkan catatan BPOM, di Indonesia terdapat sekitar 20 juta kasus keracunan pangan per tahun (Dwinanda, 2019: 1).

Permasalahan keamanan pangan dialami oleh semua negara di dunia. Menurut WHO diperkirakan $70 \%$ dari sekitar 1,5 miliar penyakit yang ditularkan melalui makanan (foodborne disease). Keracunan pangan menjadi penyebab penyakit diare dan setiap tahunnya menyebabkan sekitar tiga juta kematian anak berusia di bawah 5 tahun. Contoh kasus di Amerika Serikat diperkirakan terdapat 48 juta kasus keracunan makanan setiap tahunnya. Berdasarkan data tahun 1998, kejadian keracunan makanan di Amerika Serikat mengakibatkan 128.000 orang dirawat di rumah sakit dan sekitar 3.000 orang meninggal dunia. Pada tahun 2000 di Jepang juga pernah terjadi kasus besar yaitu keracunan produk susu yang diproduksi oleh perusahaan Snow Brand Milk Products Co., Ltd, yang tercemar staphylococcus aureus dan mengakibatkan lebih dari 14.000 orang mengalami keracunan. Sementara di Indonesia, berdasarkan data BPOM pada periode tahun 2009-2013 diperkirakan ada 10.700 kasus kejadian luar biasa keracunan pangan dan selama periode tersebut, terdapat 411.500 orang sakit dan 2.500 orang meninggal dunia (Surono, Sudityo, \& Waspodo, 2016: 19).

Di sisi lain, kondisi yang membahayakan kesehatan dan jiwa konsumen setelah mengonsumsi pangan yang tidak aman sebagaimana diuraikan di atas, menunjukkan masih lemahnya kedudukan masyarakat sebagai konsumen. Hal ini dikarenakan faktor kurangnya informasi dan pengetahuan tentang pangan yang aman dikonsumsi dan dampak yang dapat terjadi jika mengonsumsi pangan yang tidak aman. Untuk itu, masyarakat perlu mendapat jaminan perlindungan setiap kali membeli produk pangan. Jaminan perlindungan pada masyarakat sebagai konsumen tersebut merupakan bagian yang tidak terpisahkan dalam setiap kegiatan bisnis. Setiap kegiatan bisnis yang baik harus ada upaya perlindungan hukum kepada konsumen dan produsen secara seimbang. Jika upaya perlindungan hukum tersebut tidak seimbang, akan merugikan salah satu pihak (biasanya pihak konsumen). Ketidakseimbangan perlindungan hukum tersebut rawan terjadi pada jenis produk yang terbatas. Produsen dapat menyalahgunakan posisinya yang monopolistik dan pada akhirnya konsumenlah yang banyak dirugikan. Untuk itu, perlu adanya peningkatan upaya perlindungan pada konsumen sehingga hak-hak konsumen dapat ditegakkan (Hura, Njatrijani, \& Mahmudah, 2016: 3).

Berdasarkan uraian tersebut, keamanan pangan penting bagi kelangsungan hidup suatu bangsa dan merupakan bagian dari hak asasi manusia. Namun, kita masih dihadapkan dengan permasalahan seputar peredaran pangan yang tidak aman dikonsumsi di masyarakat walaupun secara legal formal sudah ada pengaturannya. Kondisi ini sebagai indikasi perlunya perhatian lebih dari semua pihak terkait dalam penyelenggaraan keamanan pangan sehingga masyarakat sebagai konsumen dapat terlindungi dari pangan yang tidak aman, mengingat efek yang ditimbulkan dapat berpengaruh pada kualitas sumber daya manusia (SDM) Indonesia di masa datang (Haryadi \& Andarwulan, 2018: 18).

Berdasarkan permasalahan tersebut, maka pertanyaan penelitiannya adalah bagaimana gambaran kondisi penyelenggaraan keamanan 
pangan di Indonesia? Faktor apa saja yang perlu diperhatikan dalam penyelenggaraan keamanan pangan agar hak masyarakat sebagai konsumen dapat terlindungi?

Tulisan ini menggunakan studi pustaka yang analisisnya didasarkan pada teori dan konsep yang diambil dari berbagai literatur kepustakaan, jurnal, media cetak, internet, dan dokumen yang terkait keamanan pangan. Tulisan ini ditujukan untuk memberikan informasi terkait kondisi penyelenggaraan keamanan pangan di Indonesia dan berbagai faktor yang perlu diperhatikan dalam penyelenggaraan keamanan pangan agar hak masyarakat sebagai konsumen dapat terlindungi.

Manfaat dari tulisan ini diharapkan dapat memberikan masukan dan bahan pertimbangan bagi pengambil kebijakan, khususnya anggota Dewan dalam melakukan revisi UU Pangan, UU Kesehatan, dan penyusunan draf Rancangan Undang-Undang tentang Pengawasan Obat dan Makanan.

\section{Keamanan Pangan}

Menurut WHO, keamanan pangan (food safety) adalah suatu ilmu yang membahas tentang persiapan, penanganan, dan penyimpanan makanan atau minuman agar tidak terkontaminasi oleh bahan fisik, biologi, dan kimia. Tujuan utama keamanan pangan adalah untuk mencegah makanan dan minuman agar tidak terkontaminasi oleh zat asing baik fisik, biologi, maupun kimia sehingga dapat mengurangi potensi terjadinya sakit akibat bahaya pangan. Kontaminasi fisik adalah benda asing yang masuk ke dalam makanan atau minuman. Contohnya rambut, logam, plastik, kotoran, debu, kuku, dan lainnya. Arti dari kontaminasi biologi adalah suatu zat yang diproduksi oleh makhluk hidup (seperti manusia, tikus, kecoa, dan lainnya) yang masuk ke dalam makanan atau minuman. Kontaminasi kimia meliputi herbisida, pestisida, serta obatobatan hewan. Kontaminasi kimia ada juga yang bersumber dari lingkungan seperti udara atau

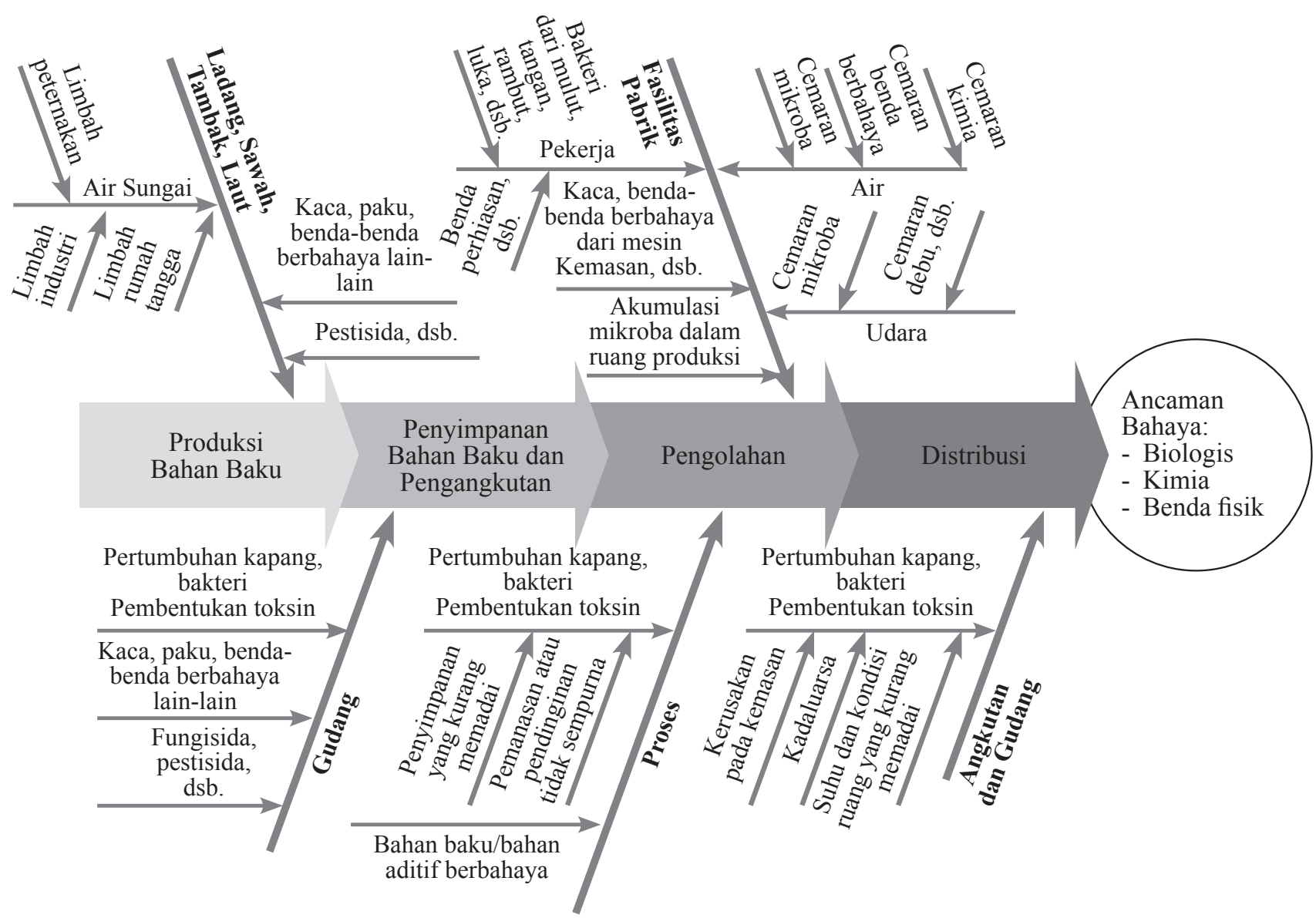

Bagan 1. Asal-Usul Berbagai Bahaya yang Mungkin Terjadi dalam Proses Produksi Produk Makanan Sumber: Surono, Sudityo, \& Waspodo, 2018: 9 
tanah serta polusi air. Ada juga migrasi dari kemasan makanan, penggunaan zat adiktif atau racun alami, serta kontaminasi silang yang terjadi selama makanan diproses (Knechtges, 2014: 3536).

Asal usul ancaman bahaya kontaminasi fisik, biologi, dan kimia dapat ditelusuri sejak bahan baku diproduksi (terkait dengan bidang pertanian, perkebunan, peternakan atau perikanan), pascapanen (terkait dengan pengangkutan dan penyimpanan atau penggudangan), pengolahan, distribusi sampai produk pangan siap dikonsumsi (lihat Bagan 1).

Sistem keamanan pangan merupakan sistem yang sangat besar dan luas. Penerapannya berkaitan erat dengan berbagai disiplin keilmuan, seperti di antaranya teknologi pangan, mikrobiologi, kimia, toksikologi, manajemen produksi, higiene sanitasi, gizi, dan lain sebagainya.

Secara makro, sistem keamanan pangan mencakup aspek yang sangat luas dan rumit, seperti misalnya sistem pengawasan dan pengendalian (surveilans), analisis risiko, dan regulasi yang tidak saja di tingkat pemerintah lokal, tetapi juga di tingkat antarnegara dan lembaga internasional seperti WHO dan FAO. Secara mikro, sistem keamanan pangan berada pada lingkup aplikasi di industri pengolahan pangan. Sistem keamanan pangan pada tingkat ini cakupannya juga luas dan rumit, karena keragaman sifat bahan baku dan jenis produk olahan yang sangat beragam dari yang sangat rumit dan berisiko tinggi, seperti misalnya produk olahan hasil ternak (susu, telur, daging, dan lain sebagainya) oleh industri berskala besar, sampai pada produk yang berisiko relatif rendah, seperti misalnya produk olahan sirup, makanan ringan, dan sebagainya yang diolah dalam skala industri kecil menengah (IKM) (Surono, Sudityo, \& Waspodo, 2018: 23).

Jaminan keamanan pangan merupakan suatu keharusan pada industri pangan. Untuk itu, penerapan manajemen pangan sangat diperlukan. Model sistem keamanan pangan yang paling lengkap dikenal adalah sistem Hazard Analysis and Critical Control Point (HACCP) yang pertama kali dikembangkan di Amerika Serikat pada tahun 1960-an dan sampai saat ini hampir semua negara mensyaratkan sistem ini khususnya bagi industri pangan yang berorientasi ekspor (Surono, Sudityo, \& Waspodo, 2018: 8).

Sistem HACCP atau analisis bahaya dan pengendalian titik kritis merupakan suatu pendekatan ilmiah, rasional, dan sistematik untuk mengidentifikasi, menilai, dan mengendalikan bahaya. HACCP ditujukan untuk mencegah bahaya-bahaya yang sudah diketahui bahaya fisik, biologi, dan kimia serta mengurangi risiko terjadinya bahaya dengan melakukan pengendalian pada setiap titik kritis dalam proses produksi (dari tahap produksi bahan baku, pengadaan dan penanganan bahan baku, pengolahan, distribusi hingga konsumsi produk jadi) (Surono, Sudityo, \& Waspodo, 2018: 23).

Penyusunan rencana HACCP umumnya dilakukan dalam 12 langkah, yaitu tahap persiapan: menyusun tim HACCP, mendeskripsikan produk, mengidentifikasi tujuan penggunaan produk, menyusun alur proses, dan mengkonfirmasi alur proses di lapangan. Tahap kegiatan inti: menyusun daftar yang memuat semua potensi bahaya yang berhubungan pada masing-masing tahapan, melakukan analisis potensi bahaya yang telah diidentifikasi, menentukan titiktitik pengendalian kritis (critical control points - CCP), menentukan batas-batas kritis untuk masing-masing $\mathrm{CCP}$, menentukan upaya-upaya perbaikan, menyusun prosedur verifikasi, dan menyusun sistem dokumentasi dan pencatatan (Surono, Sudityo, \& Waspodo, 2018: 24).

Selain sistem keamanan pangan sebagaimana sudah diuraikan di atas, untuk menjaga keamanan pangan, ada beberapa hal yang perlu diperhatikan yaitu (Maxlean Consulting, 2019: 1):

1) Pemeliharaan bahan dasar atau bahan baku makanan dan minuman. Pemilihan bahan baku merupakan upaya pertama yang dilakukan untuk mencegah makanan dan minuman dari kontaminasi. Bahan baku harus terlindungi dari zat-zat asing yang dapat masuk ke dalam makanan.

2) Penyimpanan bahan baku makanan. Hal ini juga harus diperhatikan karena sangat berpengaruh pada kualitas bahan baku. Jika penyimpanan bahan baku makanan ini tidak diperhatikan, dapat menimbulkan kerusakan 
seperti tercemar oleh bakteri dan dapat juga menimbulkan kerusakan mekanisme seperti tekanan, benturan, gesekan, dan lainnya.

3) Pengolahan bahan baku, merupakan suatu proses pengubahan dari bahan mentah menjadi matang atau siap santap. Pada fase ini harus benar-benar diperhatikan baik cara maupun peralatan yang digunakan.

4) Penyajian. Pada saat disajikan harus sudah teruji secara klinis sehingga layak untuk dikonsumsi. Wadah yang digunakannya pun harus terbebas dari kontaminasi zat asing.

Untuk menjaga agar sistem keamanan pangan dapat dijalankan dengan baik, diperlukan pengawasan pangan. Pengawasan pangan perlu dilakukan sebagai wujud dari salah satu upaya perlindungan masyarakat sebagai konsumen. Perlu diketahui bahwa salah satu hak konsumen adalah rasa keamanan dan keselamatan dalam mengonsumsi barang dan/atau jasa. Keamanan pangan merupakan salah satu faktor penting yang harus diperhatikan dalam konsumsi sehari-hari. Pangan selain tersedia dalam jumlah yang cukup, harga yang terjangkau, juga harus memenuhi persyaratan lain, yaitu sehat, aman, dan halal.

Pengawasan pangan perlu dilakukan oleh pemerintah pusat maupun pemerintah daerah untuk memberikan perlindungan kepada masyarakat sebagai konsumen dan memastikan bahwa semua produk pangan sejak produksi, penanganan, penyimpanan, pengolahan dan distribusi dalam kondisi aman, serta layak dan sesuai untuk dikonsumsi manusia. Selain itu pengawasan pangan juga diperlukan untuk mengetahui tingkat kepatuhan produsen dalam memenuhi persyaratan keamanan dan mutu pangan, serta pemberian label dengan jujur dan tepat sesuai hukum yang berlaku (Hura, Njatrijani, \& Mahmudah, 2016: 3).

\section{Dampak Pangan Tidak Aman terhadap Kesehatan}

Pangan sangat dibutuhkan untuk keberlangsungan hidup manusia. Mengonsumsi pangan yang sehat dan aman merupakan faktor penting dalam meningkatkan kesehatan masyarakat. Untuk itu, kualitas dan keamanan pangan baik secara fisik, biologi, maupun kimia perlu dijaga agar hak masyarakat sebagai konsumen dapat terlindungi dari penyakit karena makanan, penyakit bawaan makanan dan/atau keracunan makanan.

Terkait penyakit bawaan makanan, ada beberapa klasifikasi untuk penyakit yang ditularkan

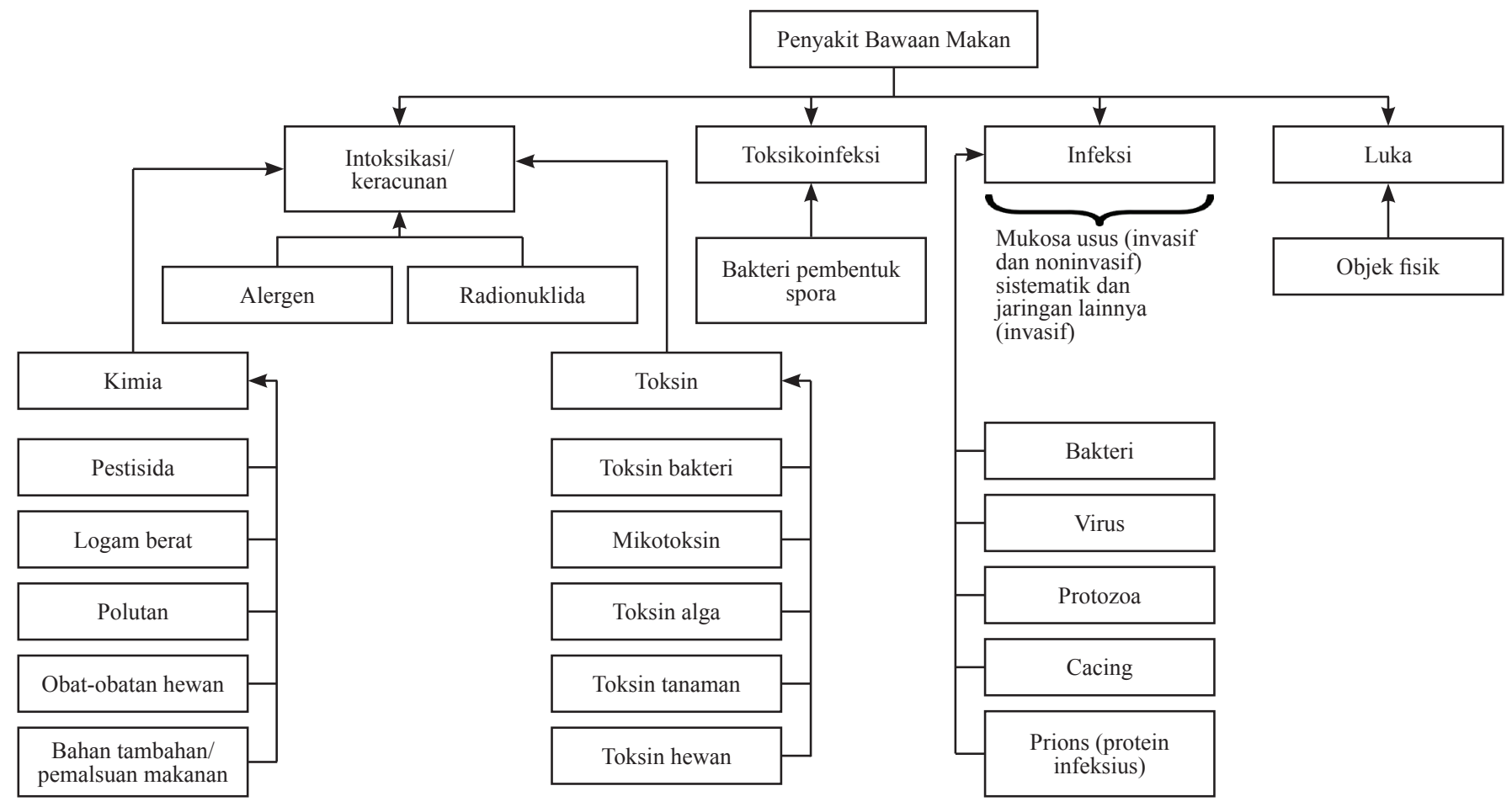

Bagan 2. Klasifikasi Penyakit yang Ditularkan melalui Makanan Sumber: Knechtges, 2014: 31 
melalui makanan secara akut (menimbulkan gejala klinis secara cepat/sesaat setelah mengonsumsi) dan subkronis (menimbulkan gejala klinis dalam hitungan jam, hari, atau minggu), seperti terlihat di Bagan 2.

Bagan 2 menunjukkan bahwa secara garis besar penyakit bawaan makanan da-pat menimbulkan keracunan/intoksikasi, toksikoinfeksi, infeksi, dan luka. Secara umum isti-lah keracunan makanan digunakan untuk menyebutkan semua penyakit yang ditularkan melalui makanan, padahal keracunan makanan hanya mewakili satu kemungkinan kategori dari penyakit yang ditularkan melalui makanan. Keracunan atau intoksikasi terjadi sebagai akibat dari mencerna bahan kimia, toksik, alergen, atau radio nuklir. Racun mewakili jenis khusus dari zat racun karena diproduksi secara biokimia oleh organisme hidup. Sejumlah variasi racun terdapat secara alami, dan racun jenis ini masuk ke dalam rantai makanan melalui perantara baik hewani atau nabati. Ada juga racun alami yang diproduksi oleh mikroorganisme beracun yang mengontaminasi makanan sedangkan bahan kimia yang diproduksi secara sintetis dan nonbiologis dapat menghasilkan racun dari berbagai sumber. Zat kimia dalam jumlah tertentu dapat merugikan kesehatan ketika dikonsumsi. Beberapa racun dan zat kimia merupakan enterotoksin dan berdampak keracunan pada sistem pencernaan, dapat juga bersifat neurotoksik yang berdampak keracunan pada organ dan sistem saraf. Menurut Bryan (1982: 2-77), pangan yang terkontaminasi dapat menyebarkan atau menyebabkan lebih dari 200 jenis penyakit.

Keracunan pangan dapat juga menimbulkan reaksi alergi, namun tidak semua reaksi alergi dikarenakan keracunan. Ada juga reaksi alergi yang disebabkan karena intoleransi makanan yang merupakan reaksi sensitif berlebihan terhadap makanan atau bahan campuran tertentu tanpa keterlibatan sistem imun. Kebanyakan intoleransi makanan adalah disebabkan faktor keturunan atau ditemukan adanya defisiensi metabolisme. Contoh yang umum ditemukan adalah intoleransi terhadap laktosa. Kondisi ini terjadi jika seseorang kekurangan enzim laktase (enzim yang diperlukan untuk mencerna laktosa susu). Keracunan jenis radionuklida biasanya dikarenakan aktivitas manusia yang berhubungan dengan limbah dari pusat pembangkit tenaga nuklir atau pengujian senjata nuklir. Keracunan radionuklida dapat juga ditemukan pada manusia yang aktivitasnya berhubungan dengan limbah industri (biasanya pada pertambangan), pengobatan (radioterapi), dan lembaga riset di bidang radionuklida (Knechtges, 2014: 30).

Masalah kesehatan lain yang ditularkan melalui pangan yang tidak aman adalah infeksi oleh mikroorganisme patogen dan parasit. Jenis penyakit infeksi ini paling umum terjadi dan menyerang saluran pencernaan. Patogen dan parasit secara luas diklasifikasikan sebagai bakteri, virus, protozoa, dan cacing. Namun, perkembangan zaman memengaruhi jenis dan sifat patogen. Perubahan pertumbuhan tanaman dan pemeliharaan ternak telah membentuk ceruk ekologi baru bagi tanaman dan bahan kimia baru untuk pertanian. Sayur-sayuran banyak yang terkontaminasi oleh patogen enterik. Studi menemukan banyak jenis patogen dapat bertahan hidup di lahan melalui proses yang disebut internalisasi (Beuchat, 2006: 39; Buck, Walcott, \& Beuchat, 2003: 2). Patogen penyebab infeksi yang ditularkan dari hewan ke manusia, selama beberapa dekade lalu juga mengalami perubahan yaitu menjadi lebih ganas dan timbul jenis patogen baru. Kondisi ini terjadi sebagai akibat perubahan teknologi industrialisasi produksi hewan yang mencampurkan pakan ternak dengan antibiotik dengan tujuan pertumbuhan (Knechtges, 2014: 30).

Luka saat mengonsumsi makanan biasanya terjadi akibat dari bagian tajam atau keras pada makanan, seperti duri, tulang biji-bijian, dan lainnya. Luka juga dapat terjadi karena mengonsumsi pangan yang sudah terkontaminasi benda tajam seperti pecahan dan serpihan kaca. Kontaminasi biasanya terjadi saat pemrosesan yang tidak higienis. Semua benda tersebut dapat membahayakan ketika tercerna, bahkan dapat menyebabkan luka yang sangat serius (Knechtges, 2014: 32).

Di sisi lain, pilihan konsumen mendorong banyak perubahan di dalam pasokan pangan. Gaya hidup yang mengedepankan kepraktisan dengan lebih menyukai makan panganan dari luar rumah diiringi dengan semakin ba- 
nyaknya industri kuliner yang berimbas pada meningkatnya permintaan pasokan pangan di masyarakat. Pasokan pangan dalam bentuk kemasan dan olahan juga semakin meningkat. Bahkan pangan untuk dikonsumsi di rumahan pun saat ini semakin banyak dalam bentuk kemasan dan olahan.

Pangan kemasan dan olahan jika tidak ditangani melalui proses yang baik dapat merusak mutu dan menghilangkan atau mengurangi kandungan gizi pangan tersebut. Untuk itu, evaluasi dan kontrol yang ketat secara kontinu dengan mengedepankan keamanan pangan sangat diperlukan.

Indonesia sampai saat ini masih dihadapkan pada permasalahan klasik sebagai akibat dari dampak mengonsumsi pangan yang tidak aman yaitu keracunan dan diare. Catatan mengenai KLB karena keracunan makanan pernah disandang oleh Indonesia dan sejak tahun 2004 jumlah orang-orang yang sakit karena makanan juga meningkat (Haryadi, 2008: 18). Grafik di bawah ini (Grafik 1) merupakan salah satu contoh insiden keracunan di masyarakat yang terjadi pada tahun 2016. Insiden keracunan pada tahun 2016 paling banyak disebabkan oleh makanan (135 orang), jauh mendominasi dibanding penyebab lainnya seperti karena minuman (10 orang), binatang (6 orang), serta pestisida, dan pencemaran lingkungan ( 3 orang).

Penyebab

\begin{tabular}{rl|l} 
Binatang & 6 \\
Tumbuhan & $\mathbf{1}$ \\
Obat Tradisional & 0 \\
Kosmetika & 0 \\
Pestisida & 3 \\
Kimia & 2 \\
Napza & 1 \\
Obat & 2 \\
Pengemar Lingkungan & 3 \\
Makanan & 135 \\
Produk Suplemen & 1 \\
Minuman & 10 \\
Campuran & 3 \\
Grafik 1. Insiden Keracunan Nasional \\
Berdasarkan Penyebab, 2016 \\
Sumber: BPOM, 2016: 1
\end{tabular}

Jika dilihat berdasarkan penyebabnya, menurut data Sentra Informasi Keracunan Nasional (SikerNas), sepanjang bulan Juli sampai
September 2017 yang dikumpulkan dari 15 media massa online yang terdaftar di Dewan Pers, terdapat 39 insiden keracunan yang telah menelan korban lebih dari 1 orang, jumlah korban terdokumentasi sedikitnya 908 orang, dan korban meninggal dunia sebanyak 29 orang. Berdasarkan penyebabnya, insiden keracunan terbanyak disebabkan oleh makanan olahan jasa boga 49,76\%, kemudian disusul dengan makanan olahan rumah tangga 29,36\%, dan makanan olahan jajanan 10,38\% (lihat Grafik berikut).

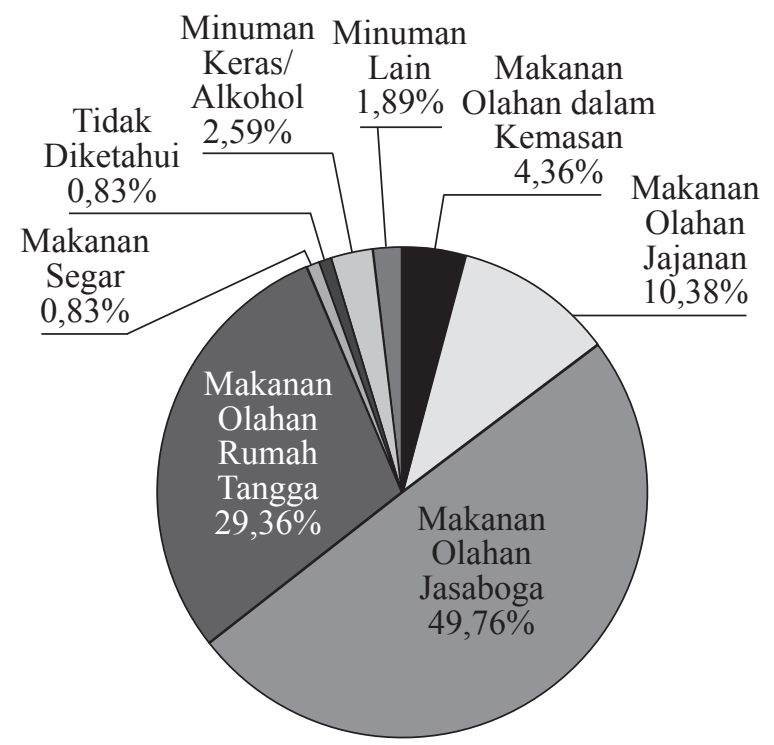

Grafik 2. Insiden Keracunan Pangan pada Media Massa Online, Juli-September 2017 Sumber: BPOM, 2018: 1

Berdasarkan data BPOM periode 2009-2013, setiap tahun permasalahan keamanan pangan menyebabkan kematian sebanyak 2.500 orang dan 411.500 orang sakit (Santosa, 2015). Selain itu, keamanan pangan dari makanan di pinggir jalan juga perlu mendapat perhatian, karena berdasarkan data BPOM 2013 sekitar 99\% anak sekolah membeli pangan jajanan di sekolah baik di dalam kantin sekolah maupun di luar sekolah (Dwinanda, 2019: 1).

Berdasarkan laporan BPOM (2018: 148), penyebab KLB keracunan pangan pada tahun 2016 teridentifikasi terbanyak adalah mikrobiologi (30\% diduga dan 3,33\% terkontaminasi) sedangkan asal pangan penyebab KLB terbanyak adalah masakan rumah tangga $49,15 \%$, pangan jajanan $20,34 \%$, jasa boga $15,25 \%$, dan pangan olahan $15,25 \%$. Kondisi ini menunjukkan bahwa praktik sanitasi dan higienis serta pengolahan pangan 
yang benar, belum dilakukan dengan baik pada tingkat rumah tangga. Hal ini sejalan dengan hasil pemeriksaan sarana produksi industri rumah tangga pangan (IRTP) bahwa terdapat 276 $(11,50 \%)$ sarana telah menerapkan cara produksi pangan yang baik (CPPOB) dan 2.104 (88,40\%) belum menerapkan CPPOB. Sedangkan untuk sarana industri pangan terdapat $1.183(63,50 \%)$ yang sudah menerapkan CPPOB dan 680 $(36,50 \%)$ belum menerapkan CPPOB secara konsisten.

Produk makanan yang beredar di dalam negeri seperti bakso, tahu, krupuk, sosis, kemplang, sirup, es manis, manisan, pempek, ikan asin, dan lainnya sering kali disinyalir mengandung formalin. Hasil pemeriksaan makanan dan bahan makanan yang mengandung bahan tambahan pengawet (BTP) seperti borak, formalin, dan pewarna tekstil, umumnya didapat pada makanan yang dijajakan di pasar tradisional dan sekolah (Nurhayati, 2009: 205). Dapat dikatakan bahwa saat ini Indonesia dalam kondisi darurat formalin dan borak. Berdasarkan hasil penelitian BPOM terhadap 700 sampel produk makanan yang diambil di Pulau Jawa, Sulawesi Selatan, dan Lampung pada awal 2016, didapat $56 \%$ mengandung formalin. Bahkan ditemukan $70 \%$ mi basah mengandung formalin. Selain itu, hasil uji sampel di DKI Jakarta yang diambil dari pasar tradisional dan swalayan di wilayah Pasar Muara Karang, Muara Angke, dan Rawamangun, diperoleh hasil 56 dari 98 sampel makanan yang positif mengandung formalin (BPOM, 2016: 125).

Produk impor seperti buah-buahan segar, makanan ringan, permen, minuman manis, dan lainnya yang seharusnya telah memenuhi standar keamanan pangan dan memiliki izin edar di Indonesia, faktanya tidak sedikit mengandung formalin yang membahayakan kesehatan (Kurnia, 2009: 1). Kondisi ini sangat memprihatinkan karena seharusnya produk impor untuk bisa masuk ke Indonesia harus memenuhi persyaratan dan standar keamanan pangan, namun sebaliknya produk impor dapat menjadi tidak berkualitas dan membahayakan keselamatan jika tetap masuk dan beredar di Indonesia tanpa memenuhi persyaratan dan standar (legalitas) sebagaimana tercantum dalam PP Nomor 86 Tahun 2019 tentang Keamanan Pangan Pasal 42. Hal ini tentunya sebagai cerminan bahwa pengawasan terhadap impor pangan masih lemah sehingga perlu mendapat perhatian lebih dan pengawasan tersendiri.

Selain itu, tidak sedikit produk pangan yang masuk ke Indonesia tanpa disertai informasi yang jelas pada kemasan produknya. Informasi yang tidak jelas pada kemasan produk impor tersebut dapat dikarenakan menggunakan bahasa asing dan tidak disertai dengan bahasa Indonesia yang komunikatif. Akibatnya para konsumen tidak paham isi dan komposisi produk tersebut. Ada juga informasi yang tercantum pada kemasan dimanipulasi yaitu menyembunyikan bahan kimia yang berbahaya dan terkandung dalam produk pangan, seperti di antaranya formalin, borak, dan Rhodamin B (Ernawaty \& Mardiah, 2013: 3).

Terkait dengan kandungan formalin dalam produk pangan, kondisi ini sangat meresahkan masyarakat karena tidak ada level aman formalin jika tertelan manusia. Artinya formalin tidak untuk dikonsumsi walau hanya sedikit. Kondisi ini merupakan masalah besar karena menyangkut masa depan SDM sebagai generasi bangsa. Dampak buruk bagi kesehatan jika terpapar formalin secara kronik dan berulang antara lain sakit kepala, radang hidung kronis (rhinitis), mual, gangguan pernapasan (seperti batuk kronis atau sesak napas kronis). Pada sistem saraf, dapat menyebabkan gangguan berupa susah tidur, sensitif, mudah lupa, dan sulit konsentrasi. Pada perempuan dapat menyebabkan gangguan menstruasi dan infertilitas. Jika terpapar formalin dalam jangka panjang, dapat menyebabkan kanker mulut dan tenggorokan (Surono, Sudityo, \& Waspodo, 2016: 19).

\section{Penyelenggaraan Keamanan Pangan di Indonesia}

Menurut analisis penulis, Indonesia menganut sistem berbagai lembaga (multiple agency system) dalam pengorganisasian pengawasan keamanan pangan. Gambaran pengorganisasian pelaksanaan pengawasan keamanan pangan secara multiple agency system tersebut dan kompilasi dari ketentuan dalam UU Pangan dan UU Kesehatan beserta peraturan pelaksanaannya dapat dilihat pada tabel berikut: 
Tabel 1.

Kelembagaan Pengawasan Produk Pangan di Indonesia

\begin{tabular}{lll}
\hline \multicolumn{1}{c}{ Jenis Pangan } & \multicolumn{1}{c}{ Regulator } & \multicolumn{1}{c}{ Pengawas } \\
\hline Pangan segar (asal hewan, asal & Kementerian Pertanian, & Pemerintah kabupaten/kota \\
tumbuhan dan asal perikanan) & Kementerian Kelautan dan Perikanan & \\
Pangan olahan industri besar & BPOM & BPOM \\
Pangan olahan industri RT & Kementerian Kesehatan & Pemerintah kabupaten/kota \\
Pangan siap saji & Kementerian Kesehatan & Pemerintah kabupaten/kota \\
\hline
\end{tabular}

Sumber: Diolah dari Berbagai Sumber

Terkait pelaksanaan pengawasan pangan, maka produk pangan terbagi dalam empat macam yaitu pangan segar yang berada di bawah pengawasan Kementerian Pertanian dan Kementerian Kelautan dan Perikanan, pangan olahan industri besar di bawah pengawasan BPOM, sedangkan pangan olahan industri rumah tangga dan pangan siap saji, di bawah pengawasan Kementerian Kesehatan.

Namun demikian, penulis berpendapat karena kurangnya komunikasi dan informasi, maka masyarakat umumnya lebih mengenal lembaga yang bertugas melakukan pengawasan pangan adalah BPOM sehingga jika terjadi kasus beredarnya pangan yang tidak aman atau ilegal yang berpotensi menimbulkan efek negatif bagi kesehatan masyarakat, yang pertama kali ditanyakan atau dimintakan klarifikasi oleh masyarakat adalah pihak BPOM.

Sebagai contoh kasus yang pernah terjadi di Indonesia yaitu kasus beras yang dioplos dengan beras palsu dari plastik (Rezy, 2015: 1) dan buah impor yang mengandung bakteri berbahaya bagi kesehatan (Afif, 2015: 1). Ketika berita ini mulai meluas, maka lembaga yang pertama dimintakan konfirmasinya oleh media massa adalah BPOM. Padahal kewenangan BPOM hanya melakukan pengawasan pada produk pangan olahan industri besar saja.

Ketika dikaitkan dengan upaya pencegahan dan penanganan kasus peredaran pangan yang tidak aman, dengan kondisi multiple agency system ini terkesan tidak efisien karena melibatkan jalur birokrasi yang tidak pendek di setiap lembaga terkait tersebut. Apalagi jika kolaborasi dan koordinasi antarlembaga pengawas pangan tersebut tidak ada atau masih rendah karena masih adanya ego sektor.
Berkaca dari pengalaman tersebut, perlu kiranya dipertimbangkan model single authority seperti yang ada di Amerika Serikat dengan nama US Food and Drug Administration (US FDA) atau di negara China dengan nama China FDA sebagai referensi atau rujukan model sistem pengawasan makanan yang juga memperhatikan kondisi sosial, budaya dan geografi Indonesia. Keberadaan kedua lembaga di kedua negara tersebut dikhususkan untuk mengatur segala sesuatu mulai dari perizinan, produksi, sampai pengawasan terkait peredaran dan konsumsi obat dan makanan di masyarakat.

Terkait penyelenggaraan keamanan pangan oleh BPOM. Pelaksanaan pengawasan peredaran makanan dan minuman pada tingkat nasional dan provinsi dilakukan oleh BPOM. BPOM merupakan lembaga nondepartemen yang bertanggung jawab kepada Presiden. Untuk tingkat kabupaten/kota, lembaga yang melakukan pengawasan adalah Balai Besar Pengawas Obat dan Makanan (BBPOM) atau Balai Pengawas Obat dan Makanan (Balai POM) yang merupakan salah satu Unit Pelaksana Teknis (UPT) dari BPOM.

Menurut BPOM dalam Ernawaty \& Mardiah (2013: 2) ada tujuh prinsip dasar sistem pengawasan makanan dan minuman, yaitu:

1) Tindakan pengamanan cepat, akurat dan profesional.

2) Tindakan dilakukan atas tingkat risiko dan berbasis bukti-bukti ilmiah.

3) Lingkup pengawasan menyeluruh, mencakup seluruh proses.

4) Berskala nasional/lintas provinsi, dengan jaringan kerja internasional.

5) Otorisasi yang menunjang penegakan supremasi hukum. 
6) Memiliki jaringan laboratorium nasional yang kohesif dan kuat yang berkolaborasi dengan jaringan global.

7) Memiliki jaringan sistem informasi keamanan dan mutu produksi.

Keamanan pangan merupakan keadaan yang sangat penting dalam kehidupan, baik bagi produsen pangan maupun konsumen. Produsen harus tanggap dan sadar bahwa kesadaran masyarakat sebagai konsumen saat ini semakin tinggi sehingga menuntut perhatian yang lebih besar. Untuk dapat memudahkan penyelenggaraan keamanan pangan, pemerintah perlu menyediakan aturan yang jelas dan tegas guna melindungi produsen pangan sekaligus masyarakat sebagai konsumen pangan. Sampai saat ini ada beberapa pengaturan terkait keamanan pangan di Indonesia, yaitu:

\section{1) Undang-Undang Nomor 18 Tahun 2012 tentang Pangan}

Pada ketentuan umum, keamanan pangan didefinisikan sebagai suatu kondisi dan upaya yang diperlukan untuk mencegah pangan dari kemungkinan cemaran biologis, kimia, dan benda lain yang dapat mengganggu, merugikan, dan membahayakan kesehatan manusia serta tidak bertentangan dengan agama, keyakinan, dan budaya masyarakat sehingga aman untuk dikonsumsi. Ketentuan ini menyatakan kondisi suatu pangan yang aman dan layak konsumsi. Hal ini sangat berpengaruh pada keselamatan masyarakat sebagai konsumen sekaligus sebagai perwujudan dari pemenuhan hak konsumen dari segi kesehatan, agama, keyakinan, dan budayanya.

Pengaturan mengenai keamanan pangan khusus diatur pada Bab VII. Pasal 69 menyebutkan bahwa penyelenggaraan keamanan pangan dilakukan melalui:

a) Sanitasi pangan;

b) Pengaturan terhadap bahan tambahan pangan;

c) Pengaturan terhadap pangan produk rekayasa genetik;

d) Pengaturan terhadap iradiasi pangan;

e) Penerapan standar kemasan pangan;

f) Pemberian jaminan keamanan pangan dan mutu pangan; dan g) Jaminan produk halal bagi yang dipersyaratkan.

Ketentuan mengenai pemberian bahan tambahan pada pangan sebagaimana yang biasa ditemukan di masyarakat dari pangan yang tidak aman dikonsumsi (mengandung formalin, borak, atau pewarna tekstil), terdapat pada Pasal 75 yang berbunyi:

“(1) Setiap orang yang melakukan produksi pangan untuk diedarkan dilarang menggunakan:

a. Bahan tambahan pangan yang melampaui batas maksimal yang ditetapkan; dan/ atau

b. Bahan yang dilarang digunakan sebagai bahan tambahan pangan.

(2) Ketentuan mengenai ambang batas maksimal dan bahan yang dilarang sebagaimana dimaksud dalam ayat (1) diatur berdasarkan peraturan pemerintah."

Pengaturan Pasal 75 pada intinya menekankan bahwa meskipun bahan tambahan pangan diperbolehkan, namun penggunaannya dilarang melewati batas. Ketentuan ini sejalan dengan UU Perlindungan Konsumen Pasal 8 huruf i yang intinya berbunyi pelaku usaha harus mencantumkan komposisi dan ukuran bahanbahan yang digunakan.

Terkait penggunaan bahan tambahan pangan secara teknis diatur lebih lanjut dalam Peraturan Menteri Kesehatan Nomor 033 Tahun 2012 tentang Bahan Tambahan Pangan.

\section{2) Undang-Undang Nomor 36 Tahun 2009 tentang Kesehatan}

Pengaturan pada UU Kesehatan Pasal 109 sampai Pasal 112, lebih menekankan pada pengamanan makanan dan minuman dari bahan yang membahayakan kesehatan pada produk makanan dan minuman. Produksi makanan dan minuman yang akan dipasarkan oleh pelaku usaha harus memenuhi standar dan/atau persyaratan kesehatan sehingga tidak membahayakan konsumen atau tidak memiliki risiko yang dapat menimbulkan masalah kesehatan. UU juga mengatur jika kedapatan melanggar, maka izin edar 
akan dicabut dan produk akan disita untuk dimusnahkan sesuai dengan peraturan perundang-undangan.

Pengaturan terkait keamanan pangan tersebut, disusun atas dasar pemenuhan hak-hak rakyat sebagai konsumen dari penyalahgunaan atau tindakan sewenang-wenang yang dilakukan oleh produsen, importir, distributor, dan setiap pihak yang berada dalam jalur perdagangan produk pangan. Selain itu, faktor keamanan, keselamatan, kesehatan, dan lingkungan juga menjadi hal yang sangat penting dalam memberikan perlindungan kepada masyarakat sebagai konsumen. Walaupun di sisi lain, masyarakat juga masih belum sepenuhnya memiliki etika moral yang baik. Hal ini terlihat dari masih adanya oknum masyarakat yang memanfaatkan sesuatu yang dapat membahayakan kesehatan masyarakat demi sebuah keuntungan dalam bisnis, contohnya dicampurnya bahan makanan dengan formalin supaya tidak mudah basi atau tahan lama sehingga lebih menguntungkan seperti yang sudah diuraikan di atas. Untuk itu, kebijakan publik tentang keamanan pangan harus benar-benar diawasi, mengingat dampak yang ditimbulkan dapat menyangkut kepentingan pokok masyarakat luas. Pengawasan pangan bukan kewenangan satu instansi saja melainkan dilakukan secara lintas sektor secara konkrit dan berkesinambungan serta kontinu.

Perlindungan masyarakat ini, menjadi kewajiban bagi pemerintah. Pemerintah wajib melakukan berbagai upaya agar semua pangan yang dikonsumsi masyarakat tidak mengandung zat-zat yang membahayakan kesehatan. Pemerintah juga harus menjamin semua produk pangan yang beredar di Indonesia dalam keadaan aman dan layak konsumsi.

\section{Faktor yang Perlu Diperhatikan dalam Penyelenggaraan Keamanan Pangan}

Globalisasi industri pangan, telah menggeser pola distribusi produk pangan. Pola distribusi bergeser menjadi globalisasi rantai pasokan makanan dan minuman disertai industrinya. Keamanan pangan telah menjadi persyaratan utama jika akan mengekspor produk pangan. Ketatnya persyaratan keamanan pangan yang sesuai dengan standar internasional sering kali menjadi hambatan bagi produsen pangan Indonesia dalam menembus pasar internasional. Tidak jarang kerugian ekonomi sebagai akibat hambatan dan penolakan produk pangan dalam perdagangan internasional harus ditanggung. Sebagai contoh, dalam dua tahun terakhir, ada 29 produk perikanan dari Indonesia (59\%) yang mengalami penolakan ketika masuk ke pasar Amerika Serikat dikarenakan dinilai tidak memenuhi persyaratan. Berdasarkan data Asosiasi Tuna Indonesia (Astuin) yang dihimpun dari US FDA terdapat $27 \%$ produk perikanan yang diduga mengandung bakteri salmonella dan 14\% diduga mengandung histamin yang berpotensi menyebabkan alergi bagi yang mengonsumsinya (Rosalina, 2017: 1).

Untuk itu, peningkatan standar produk pangan agar sesuai dengan standar kebutuhan pasar ekspor penting dilakukan. Kondisi ekspor produk pangan Indonesia terdiri dari produk pangan segar dan pangan olahan. Ekspor produk pangan segar terdiri dari produk hasil pertanian, perkebunan dan peternakan/perikanan, di antaranya beras, beras ketan, jagung, kedelai segar, kacang tanah segar, kedelai segar, kacang tanah segar, kacang hijau, ubi kayu, ubi jalar, talas, ikan, udang dan lainya. Pada bulan Januari sampai Juni, Indonesia sudah mengekspor 15 ribu ton ke sekitar 29 negara seperti Hong Kong, Singapura, Australia, Amerika, Italia, China, Thailand, Filipina, Malaysia, India, Pakistan, dan sebagainya (Kurnia, 2019: 1).

Biasanya angka yang tercatat hanya sebagian kecil saja dari kondisi yang sebenarnya terjadi di masyarakat. Fenomena ini biasa disebut sebagai fenomena gunung es, di mana terjadi under reporting sehingga data yang tercatat hanya sebagian kecil dari kejadian yang sesungguhnya. Berdasarkan catatan WHO, fenomena gunung es ini juga terjadi di negara maju di mana sistem pencatatan data dan pelaporan sudah mapan. Di negara-negara industri maju, menurut WHO hanya sekitar $10 \%$ dari kejadian yang berhasil dicatat oleh lembaga-lembaga resmi. Sementara di negara-negara berkembang (seperti Indonesia), fenomena gunung es diperkirakan data yang tercatat kurang dari 1\% kejadian pangan tidak aman yang sesungguhnya. Menurut WHO dari 
setiap 1 orang atau kasus yang berkaitan dengan penyakit karena mengonsumsi pangan tidak aman di negara berkembang, maka paling tidak terdapat 99 orang atau kasus yang tidak tercatat (Haryadi, 2008: 19).

Keberadaan keamanan pangan sangat penting karena selain dapat menimbulkan masalah kesehatan dan kematian, dapat juga berdampak pada ekonomi negara. Hal ini dikarenakan, makanan dan minuman yang dikonsumsi akan menentukan keadaan tubuh ke depan dari orang yang mengonsumsinya. Contohnya, jika kita mengonsumsi makanan yang sudah terkontaminasi bakteri, maka tubuh akan terserang penyakit akibat bakteri tersebut.
Setiap produk pangan yang beredar di pasaran, seharusnya sudah melewati proses kelayakan dan sudah dipastikan aman, layak dikonsumsi serta dapat diperdagangkan. Namun, pada kenyataannya, tidak sedikit pangan yang diedarkan tidak aman dan tidak layak konsumsi sehingga dapat menimbulkan masalah kesehatan. Selain berkaitan erat dengan kesehatan, secara umum keamanan pangan juga berkaitan dengan kualitas SDM dan daya saing bangsa. Upaya peningkatan jaminan keamanan pangan juga erat kaitannya dengan peningkatan daya saing bangsa (lihat Bagan 3).

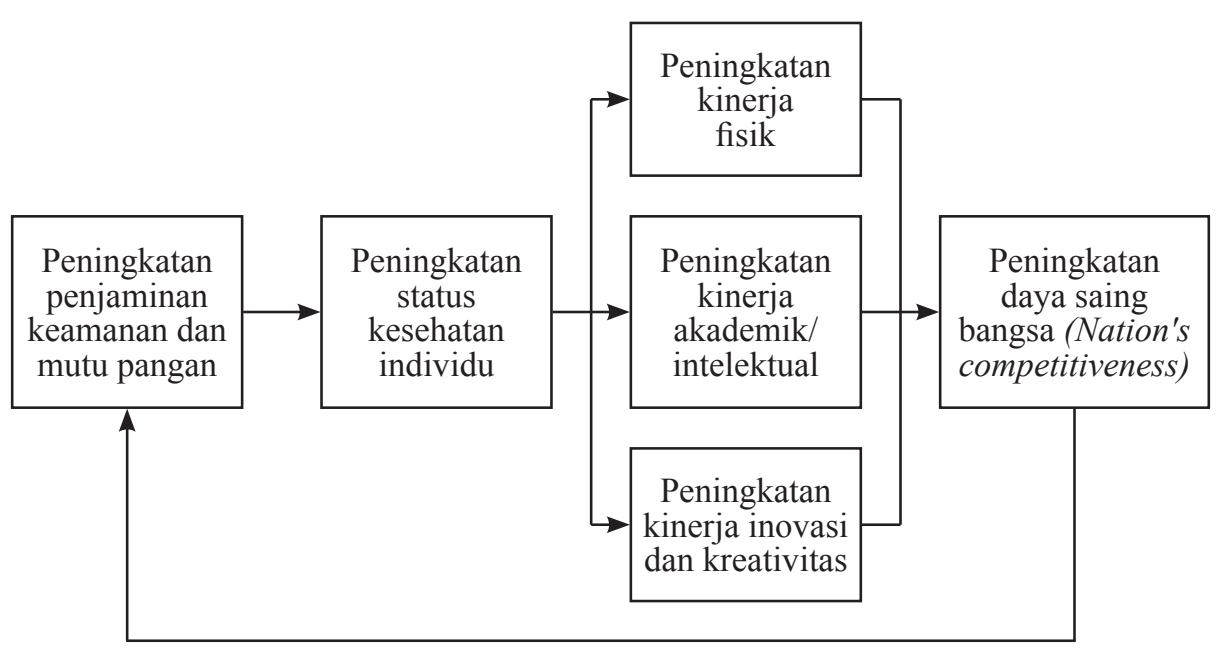

\section{Bagan 3. Peningkatan Penjaminan Keamanan Pangan akan Bermuara pada Peningkatan Daya Saing Bangsa \\ Sumber: Haryadi, 2018: 27}

Secara operasional, keamanan pangan adalah suatu risiko yang dapat diterima dan ditolerir atas keadaan sakit, penyakit atau cedera yang diakibatkan dari konsumsi makanan. Hal ini dapat dicapai melalui kebijakan, peraturan, standar, penelitian, rancang teknik dan teknologi, pengawasan dan pemeriksaan, serta upaya lainnya yang dapat diterapkan untuk mengurangi risiko atau pengendalian bahaya dalam rantai pasokan pangan. Batasan keadaan yang dapat diterima dan risiko yang dapat ditolerir dari mengonsumsi suatu makanan ditentukan oleh proses yang disebut analisis risiko (Knechtges, 2018: 2).

Pangan tidak aman memiliki potensi bahaya sehingga penyelenggaraan keamanan pangan harus dilakukan secara holistik, terkoordinasi, dan sistemik di sepanjang hulu hingga hilir rantai pasokan pangan. Penulis berpendapat bahwa penyelenggaraan keamanan pangan perlu dilakukan agar: (1) Menghindarkan masyarakat dari jenis pangan yang berbahaya bagi kesehatan, yang mendorong dari pengetahuan dan kesadaran pemasok terhadap keamanan pangan; (2) Memantapkan kelembagaan pangan, yang antara lain dicerminkan oleh adanya peraturanperaturan tentang keamanan pangan; dan (3) Meningkatkan jumlah industri makanan yang memenuhi ketentuan peraturan perundangundangan keamanan pangan.

Penyelenggaraan keamanan pangan dilakukan secara komprehensif mulai dari premarket sampai post-market dan melibatkan 
tiga pilar stakeholders sebagai penanggung jawab yaitu pemerintah dan/atau pemerintah daerah (government), konsumen (consumer), dan pelaku usaha (industry/trade). Saat premarket pengawasan dilakukan melalui penilaian data penunjang, pengujian laboratorium, dan sertifikasi produk sesuai dengan standar dan persyaratan yang berlaku. Sementara itu, untuk pengawasan post-market dilakukan melalui inspeksi dari produksi, distribusi, pelayanan, dan sampling serta pengujian laboratorium untuk menjamin mutu produk (Yusuf, 2008: 359).

Untuk ke depannya, prinsip perlindungan masyarakat sebagai konsumen dari pangan yang tidak aman menjadi faktor utama dan kewajiban bagi pemerintah untuk mewujudkannya. Hal ini sejalan dengan ketentuan dalam UU Perlindungan Konsumen, yang intinya mengatur agar pemerintah dan/atau pemerintah daerah bertanggung jawab untuk melakukan pembinaan dan pengawasan penyelenggaraan perlindungan konsumen. Ketentuan ini juga untuk menjamin diperolehnya hak konsumen dan pelaku usaha atau produsen serta dilaksanakannya setiap kewajiban oleh konsumen dan pelaku usaha atau produsen.

Untuk itu, upaya pengamanan pangan harus ditangani secara terpadu oleh berbagai stakeholders baik dari pihak pemerintah, pelaku usaha atau produsen, dan konsumen. Ada beberapa faktor yang perlu diperhatikan dalam penyelenggaraan keamanan pangan, yaitu terkait peran dari masing-masing stakeholders tersebut (pihak pemerintah, pelaku usaha atau produsen, dan masyarakat sebagai konsumen).

Jika merujuk pada WHO, ada lima faktor yang perlu diperhatikan untuk penyediaan pangan yang aman, yaitu (Yolenda, 2018: 1):

1) Menjaga kebersihan. Mencuci tangan dengan menggunakan sabun dan air bersih sebelum memasak atau menyediakan pangan. Hindari sentuhan tangan karena melalui sentuhan tangan, umumnya akan terjadi pencemaran makanan. Mikroorganisme yang melekat pada tangan akan berpindah ke makanan dan berkembang biak dalam makanan, terutama pada makanan jadi. Gunakan sarung tangan atau alat bantu seperti sendok dan lainnya pada saat akan bersentuhan dengan makanan.
2) Jaga makanan dari peluang terjadinya pencemaran. Pangan atau bahan pangan harus disimpan di tempat yang tertutup dan terbungkus dengan baik agar tidak berpeluang terkena debu. Pisahkan pangan mentah dengan yang matang dan berdasarkan jenisnya, demikian juga untuk peralatannya.

3) Simpan makanan pada suhu yang aman, seperti di lemari es jika memang makanan atau bahan makanan seharusnya disimpan dalam lemari es sehingga tidak mudah rusak atau busuk. Jangan simpan makan dalam jangka waktu terlalu lama. Makanan yang sudah matang sebaiknya jangan disimpan dalam suhu ruangan melebihi waktu 4 jam karena dikhawatirkan adanya bakteri yang berkembang biak.

4) Lakukan proses pemanasan makan dalam suhu yang benar-benar panas sebelum dikonsumsi agar mikroorganisme tidak tumbuh dan berkembang biak dengan cepat.

5) Gunakan air dan bahan baku yang aman yaitu yang tidak berwarna dan tak berbau.

Selain kelima faktor tersebut, hal yang tidak kalah pentingnya adalah faktor dukungan pemerintah dan/atau pemerintah daerah yang salah satunya melalui pembinaan dan pengawasan untuk meminimalisir risiko yang mungkin terjadi di wilayahnya. Pembinaan dan pengawasan tersebut hakikatnya untuk menjamin semua produk pangan yang beredar di masyarakat dalam keadaan aman dan layak konsumsi. Setiap peraturan yang dikeluarkan akan menjadi jaminan yang dapat menekan pelaku usaha atau produsen untuk selalu mengedarkan pangan yang layak konsumsi. Pemerintah dalam pelaksanaan pembinaan dan pengawasan tersebut berkoordinasi dengan instansi terkait. Pembagian tugas dan tanggung jawab serta koordinasi antar-semua instansi terkait tersebut menjadi kunci penting keberhasilan penyelenggaraan perlindungan konsumen dari peredaran pangan yang tidak aman dikonsumsi.

Di sisi lain, pemerintah mempunyai peran yang penting yaitu sebagai penengah dalam upaya pemenuhan kepentingan pelaku usaha atau produsen dan kepentingan masyarakat sebagai konsumen, agar masing-masing pihak 
dapat saling menghargai satu sama lain. Peran pemerintah sebagai penengah dalam hal ini ditujukan untuk mencari pemecahan masalah jika terjadi sengketa antara pelaku usaha dengan konsumen yang disebabkan adanya pelanggaran terhadap berbagai peraturan yang telah ditetapkan. Penyelesaian masalah tersebut dilakukan secara seimbang sehingga tercipta iklim usaha yang sehat dan perlindungan hak masyarakat sebagai konsumen dari pangan yang tidak aman dapat tercapai.

\section{Penutup}

Ketentuan mengenai keamanan pangan sudah diatur dalam Undang-Undang Nomor 18 Tahun 2012 tentang Pangan dan Undang-Undang Nomor 36 Tahun 2009 tentang Kesehatan. Namun dalam pelaksanaannya, ketentuan tersebut tidak cukup memadai untuk menghambat dan menghentikan penyalahgunaan bahan kimia tertentu pada produk pangan (seperti formalin, borak, pewarna tekstil, dan lain sebagainya). Hal ini menimbulkan banyaknya kasus peredaran pangan yang tidak aman di masyarakat.

Secara umum, kondisi penyelenggaraan keamanan pangan di Indonesia menganut multiple agency system yang didasarkan pada pengkategorian pangan. Pangan segar berada di bawah pengawasan Kementerian Pertanian dan Kementerian Kelautan dan Perikanan, pangan olahan industri besar di bawah pengawasan BPOM, sedangkan pangan olahan industri rumah tangga dan pangan siap saji di bawah pengawasan Kementerian Kesehatan. Kondisi seperti ini tidak efisien karena melibatkan jalur birokrasi yang tidak pendek di setiap lembaga terkait, membingungkan masyarakat, serta rawan terjadinya ego sektor. Faktor utama dalam penyelenggaraan keamanan pangan adalah menjamin terselenggaranya perlindungan masyarakat dari pangan yang tidak aman. Untuk itu, penanganan secara terpadu mulai dari tahap produksi sampai dikonsumsi oleh berbagai stakeholders baik dari pihak pemerintah, pelaku usaha atau produsen, dan masyarakat sebagai konsumen harus dilakukan.

\section{Daftar Pustaka}

Afif. (2015, January 27). BBPOM Aceh Mengambil Sampel Apel yang Diambil Terkandung Bakteri Listeria. Merdeka.com. Retrieved from https:// www.merdeka.com/peristiwa/bbpom-acehambil-sampel-apel-diduga-terkandung-bakterilisteria.html, on May 5, 2020.

Badan Pengawas Obat dan Makanan. (2016, December, 29). Sentra Informasi Keracunan (Siker) Nasional. Retrieved from http://ik.pom. go.id/v2016/, on May 5, 2020.

Badan Pengawas Obat dan Makanan. (2018). Laporan Tahunan 2017. Jakarta: BPOM.

Badan Pengawas Obat dan Makanan. (2018, January 30). Berita Keracunan Bulan Juli-September 2017, Informasi Kejadian Keracunan yang Diberitakan Oleh 138 Media Massa Online Pada Bulan Juli-September 2017. Retrieved from http://ik.pom.go.id/v2016/berita-keracunan/ berita-keracunan-bulab-juli-september-2017, on May 5, 2020.

Beuchat, L. R. (2006). Vector and Condition for Preharvest Contamination of Fruit and Vegetables with Pathogens Capable of Causing Enteric Diseases. British Food Journal, 108(1), $38-53$.

Bryan, F. L. (1982). Diseases Transmitted by Food (Classification and Summary). Atlanta, GA: Public Health Service, Centers for Diseases Control and Prevention, U.S. Department of Health and Human Services.

Buck, J. W., Walcott, R. R., \& Beuchat, L. R. (2003). Recent trends in microbiological safety ... Plant Health Progress, doi:10.1094/PHP- 2003-012101-RV.

Dwinanda, R. (2019, November 11). Ada 20 Juta Kasus Keracunan Pangan per Tahun di Indonesia. Republika.co.id. Retrieved from https://republika.co.id/berita/q0qmtn414/ada20-juta-kasus-keracunan-pangan-per-tahun-diindonesia, on May 5, 2020.

Ernawaty, E., \& Mardiah, M. (2013). Pelaksanaan Pengawasan terhadap Produk Makanan Impor oleh Balai Besar Pengawas Obat dan Makanan (BBPOM) di Kota Pekanbaru. Jurnal Online Mahasiswa Fakultas Ilmu Sosial dan Ilmu Politik Universitas Riau, 1(1), Feb. 2014. 
Haryadi, P. (2008). Beban Ganda: Permasalahan Keamanan Pangan di Indonesia. Jurnal Pangan, 51(XVII), 17-27.

Haryadi, P. \& Andarwulan, N. (2018). Peningkatan Penjaminan Keamanan dan Mutu Pangan untuk Pencegahan Stunting dan Peningkatan Mutu SDM Bangsa dalam Rangka Mencapai Tujuan Pembangunan Berkelanjutan, Makalah Utama Kelompok Kerja 3 Widyakarya Nasional Pangan dan Gizi XI 2018, Jakarta, July 3-4, 2018.

Hura, D. L., Njatrijani, R., \& Mahmudah, S. (2016). Perlindungan Bagi Konsumen Terhadap Makanan Olahan Mengandung Bahan Berbahaya Di Jawa Tengah. Diponegoro Law Journal, 5(4), $1-18$.

Kartikasari, N. (2012). Peran Dinas Kesehatan Dalam Pengawasan Terhadap Peredaran Makanan Yang Mengandung Pewarna Tekstil Rhodamin B Untuk Pemenuhan Perlindungan Hukum Bagi Konsumen. Skripsi. Malang: Universitas Brawijaya.

Knechtges, P. L. (2014). Keamanan Pangan, Teori dan Praktik. Jakarta: Penerbit Buku Kedokteran EGC.

Kurnia, T. (2019, Agust 12). Indonesia Ekspor 15 Ribu Ton Pangan Segar di Semester I 2019. Liputan6. com. Retrieved from https://www.liputan6.com/ bisnis/read/4036102/indonesia-ekspor-15-ributon-pangan-segar-di-semester-i-2019, on May 5, 2020.

Maxlean Consulting. (2019, March 24). Hal Penting Dalam Sistem Manajemen Pangan. Retrieved from https://www.isomanajemen.com/sistemmanajemen-pengamanan/, on May 5, 2020.

Nugraheni, H., Wiyatini, T., \& Wiradona, I. (2018). Kesehatan Masyarakat dalam Determinan Sosial Budaya. Yogyakarta: Penerbit Deepublish.

Nurhayati, I. (2009). Efektivitas Pengawasan Badan Pengawas Obat dan Makanan Terhadap Peredaran Produk Pangan Olahan Impor Terhadap Peredaran Produk Pangan Olahan Impor Dalam Mewujudkan Perlindungan Konsumen. Jurnal Mimbar Hukum, 21(2), 203-408.

Peraturan Pemerintah tentang Keamanan Pangan (2019)

Rezy, F. (2015, May 19). Beras Plastik Ditemukan di Bekasi, BPOM Belum Bersikap. Okezone.com. Retrieved from https://economy.okezone.com/ $\mathrm{read} / 2015 / 05 / 19 / 320 / 1151915 /$ beras-plastik- ditemukan-di-bekasi-bpom-belum-bersikap, on May 5, 2020.

Rosalina, D. (2017, September 14). Nasib Tiga Komoditas Ini Terganjal Ekspor Ke AS. Kontan. co.id. Retrieved from https://industri.kontan. co.id/news/nasib-tiga-komoditas-ini-terganjalekspor-ke-as, on May 14, 2020

Santosa, U.A. (Ed.). (2015, May 1). BPOM: 2.500 orang meninggal keracunan pangan. Kontan. co.id. Retrieved from https://nasional.kontan. co.id/news/bpom-2500-orang-meninggalkeracunan-pangan, on June 10, 2020.

Surono, S., Sudibyo, A., \& Waspodo, P. (2018). Pengantar Keamanan Pangan Untuk Industri Pangan. Yogyakarta: Deepublish.

Ulya, F. N. (2019, May 20). Ramadhan, BPOM Sita Produk Pangan Tak Layak Edar Senilai Rp. 3,4 Miliar. Kompas.com. Retrieved from https://money.kompas.com/ $\mathrm{read} / 2019 / 05 / 20 / 140035226 /$ ramadhan-bpomsita-produk-pangan-tak-layak-edar-senilai-rp34-miliar, on May 5, 2020.

Undang-Undang tentang Kesehatan (2009).

Undang-Undang tentang Pangan (2012).

Undang-Undang tentang Perlindungan Konsumen (1999).

Yolenda, F. (2018, September 27). Lima Masalah Utama Keamanan Pangan. Republika.co.id. Retrieved from https://republika.co.id/berita/ pfoxdw370/ini-masalah-utama-keamananpangan, on May 5, 2020.

Yusuf, S. (2008). Kapita Selekta Hukum Perlindungan Konsumen di Indonesia. Bandung: Citra Aditya Bakti. 